DOI https://doi.org/10.30525/978-9934-26-074-2-62

\title{
ЩОДО МОЖЛИВИХ ФОРМ ЗАЛУЧЕННЯ СПЕЦІАЛІСТІВ ДОСЛІДНО-ВИПРОБУВАЛЬНИХ ЛАБОРАТОРІЙ ДСНС ДО УЧАСТІ В КРИМІНАЛЬНОМУ ПРОВАДЖЕННІ У СПРАВАХ ПО ПОЖЕЖАМ
}

\author{
Климась Р. В. \\ начальник відділу досліджень, \\ статистики пожеж та надзвичайних ситуаџій \\ Інституту державного управління та наукових досліджень \\ з циивільного захисту \\ м. Київ, Украӥна
}

В Україні питаннями розслідування та дослідження пожеж, проведення пожежно-технічних експертиз i досліджень займаються слідчі Нацполіції, експерти-пожежотехніки науково-дослідних експертно-криміналістичних центрів МВС, судові експерти науководослідних установ судових експертиз Мін'юсту, спеціалісти підрозділів Державної служби України з надзвичайних ситуацій.

Відповідно до покладених завдань [1] підрозділи Державної служби України з надзвичайних ситуацій (далі - ДСНС) беруть участь у розслідуванні пожеж, причин виникнення надзвичайних ситуацій та невиконання запобіжних заходів, а також проведенні оцінки дій органів управління і сил щодо організації та проведення ними рятувальних і інших невідкладних робіт [1].

Безпосередньо ці завдання покладено на дослідно-випробувальні лабораторії територіальних органів ДСНС (далі - ДВЛ), основним напрямом діяльності яких відповідно до керівних документів [2, 3] $\epsilon$ проведення робіт, пов'язаних із дослідженням пожеж i встановленням причин їх виникнення.

Впродовж останніх років у цілому над проблематикою залучення експертів і спеціалістів до розслідування кримінальних правопорушень працювали Азаров Ю.І., Бєлкін Р.С., Климась Р.В., Ковальов В.В., Коновалова В.Е., Лазебний А.М., Лук'янчиков Є.Д., Махов В.М., Рафальський Є.О., Романюк Б.В., Сегай М.Я., Яремчук В.О.; зокрема, питання особливостей взаємодії слідчих з експертами та спеціалістами висвітлено в праці [4]; процесуальним аспектам залучення спеціалістів ДВЛ і використанням спеціальних знань у кримінальному провадженні присвячено роботи $[5,6]$; безпосередньо проблематику залучення 
спеціалістів ДВЛ до дослідження й експертизи пожеж досліджено в роботі [7].

Наразі, із введенням у дію 2012 року нового Кримінального процесуального кодексу Украӥни [8] повністю було змінено порядок залучення співробітників ДСНС, зокрема фахівців ДВЛ, до дослідження пожеж, а по суті органи ДСНС, що виконували функції дізнання у справах про пожежі, виявилися практично відстороненими від даного процесу. Про зниження кількості пожеж, досліджених ДВЛ, щороку свідчить аналіз їх службової діяльності [7].

Прийняття відповідно до Кримінального процесуального кодексу України [8] за ініціативи Головного слідчого управління Нацполіції 3 метою вдосконалення організації взаємодії посадових осіб Націполіції, ДСНС та Експертної служби МВС на місці пожежі наказу МВС від 24.07.2017 № 621 [9], відповідно до якого територіальні органи ДСНС залучаються для установлення причин виникнення пожеж, а також обставин та умов, що сприяли їх виникненню, а посадові особи ДСНС виступають у якості спеціалістів, - у повній мірі не вирішило питання залучення спеціалістів ДСНС до дослідження пожеж і встановлення причин їх виникнення. Разом із тим, Порядок спільних дій Національної поліиії України, Державної служби України з надзвичайних ситуаџій та Експертної служби Міністерства внутрішніх справ Украӥни під час проведення огляду місия пожежі, виявлення, припинення, попередження та розслідування кримінальних правопорушень та інших подій, пов'язаних з пожежами [9] встановлює критерії [10], за якими слідчі мають залучати спеціалістів ДВЛ до дослідження пожеж, а саме: участі в огляді місця події, фіксації обстановки на місці пожежі, проведення пожежно-технічних досліджень (експертизи) та установлення обставин і причин виникнення пожежі.

Кримінальний процесуальний кодекс Украӥни [8], визначаючи спеціаліста як учасника кримінального провадження, значно розширює можливості використання слідчим його спеціальних знань і навичок, адже в ст. $128^{1}$ Кримінально-процесуального кодексу України 1960 року йшлося про участь спеціаліста лише у проведенні слідчих дій, а вже відповідно до ст. 71 чинного Кримінального процесуального кодексу України спеціаліст бере участь у кримінальному провадженні, складовими якого згідно 3 п. 10 ст. 3 [8] є досудове розслідування, судове провадження та процесуальні дії у зв'язку із вчиненням діяння, передбаченого законом про кримінальну відповідальність.

Лук'янчиков Є.Д. у своїй роботі [6] звертає увагу на те, що окрім надання практичної допомоги слідчому в застосуванні технічних або інших засобів спеціаліст може бути залучений для надання консультацій і висновків під час досудового розслідування (ст. 71 [8]), а також під час 238 
дослідження доказів у суді (ст. 360 [8]), що дозволяє стверджувати про процесуальний характер такої діяльності.

Виходячи із проведеного Лук'янчиковим С.Д. аналізу норм чинного Кримінального процесуального кодексу України [6], можна виокремити такі форми залучення фахівців дослідно-випробувальних лабораторій ДСНС у якості спеціалістів до участі в кримінальному провадженні у справах по пожежам:

1) для надання безпосередньої технічної допомоги під час досудового розслідування та судового розгляду (ч. 2 ст. 71 [8]);

2) для надання консультацій 3 питань, що потребують відповідних спеціальних знань і навичок (ч. 1 ст. 71; ч. 1 ст. 360 [8]);

3) для надання висновків $з$ питань, що належать до сфери його знань, під час досудового розслідування кримінальних проступків (ч. 2, п. 7 ч. 4 ст. 71 ; п. 3 , ч. 3 ст. 214 [8]);

4) для надання письмових роз'яснень під час дослідження доказів у суді (ч. 1 ст. 360 [8]).

Окремі вчені пропонують поділяти форми використання спеціальних знань на три групи: визначені та врегульовані [8]; визначені, але не регламентовані [8]; не визначені та не регламентовані законом. Зокрема, до першої групи можна віднести та вважати процесуальними такі дії, як участь в огляді місця події спеціаліста, запрошеного слідчим чи прокурором з метою одержання допомоги 3 питань, що потребують спеціальних знань (ст. 237 [8]). Цей поділ не можна вважати бездоганним. У той же час не викликає заперечень і думка, що слідчий, спеціаліст та експерт $є$ тими учасниками провадження, для яких використання спеціальних знань і навичок $є$ професійним обов'язком.

Інструкція про призначення та проведення судових експертиз та експертних досліджень [11] визначає основні завдання пожежнотехнічної експертиз та те, що перед нею можуть ставитися й інші завдання, пов'язані 3 провадженням у справі про пожежу, для розв'язання яких необхідні спеціальні знання в галузі пожежної справи; також передбачено, що під час оформлення матеріалів для проведення експертиз орган чи особа, які пї призначили, можуть залучати спеціалістів для відбирання зразків. Саме ці завдання можуть, маючи певний досвід, спеціальні знання та навички, вирішувати спеціалісти ДВЛ.

\section{Література:}

1. Постанова Кабінету Міністрів України від 16 грудня 2015 р. № 1052 «Про затвердження Положення про Державну службу України з надзвичайних ситуацій» (Офіційний вісник України, 2015 р., № 102, ст. 3514). 
2. Наказ Держтехногенбезпеки України від 18 травня 2012 р. № 133 «Про затвердження примірного Положення про дослідно-випробувальну лабораторію територіального органу Держтехногенбезпеки Украӥни».

3. Наказ Держтехногенбезпеки України від 21 рудня 2012 p. № 273 «Про затвердження Настанови 3 організаиії роботи дослідно-випробувальної лабораторії територіального органу Держтехногенбезпеки України».

4. Азаров Ю.І., Рафальський Є.О. Особливості взаємодії слідчого 3 експертом (спеціалістом) на початковому етапі досудового розслідування. Науковий юридичний журнал: Юридична наука. К.: № 10, 2014. С. 87-96.

5. Середа Д.В., Климась Р.В. Процесуальні аспекти залучення спеціалістів дослідно-випробувальних лабораторій територіальних органів ДСНС до участі в огляді місця події, пов'язаної з пожежею. Науковий журнал: Південноукраӥнський правничий часопис. Одеса: № 1, 2020. С. 165-167.

6. Лук'янчиков Є.Д. Використання спеціальних знань у кримінальному провадженні. Актуальні проблеми юридичної науки та практики в XXI столітmі: матеріали міжнародної науково-практичної конференції. Міжнародний економіко-гуманітарний університет імені академіка Степана Дем'янчука. Рівне: Видавничий центр «Гельветика», 2020. Ч. 2. С. $176-180$.

7. Климась Р.В. Проблемні питання залучення спеціалістів дослідновипробувальних лабораторій ДСНС до дослідження пожеж і проведення експертиз по ним. Актуальні проблеми юридичної науки та практики в XXI столітmі: матеріали міжнародної науково-практичної конференції. Міжнародний економіко-гуманітарний університет імені академіка Степана Дем'янчука. Рівне: Видавничий центр «Гельветика», 2020. Ч. 2. С. $172-176$.

8. Кримінальний процесуальний кодекс України від 13 квітня 2012 р. № 4651-VI (Відомості Верховної Ради України (ВВР), 2013 р., № 9-13, ст. 88).

9. Наказ МВС України від 24 липня 2017 р. № 621 «Про затвердження Порядку спільних дій Начіональної поліиії Украӥни, Державної служби України з надзвичайних ситуаиій та Експертної служби Міністерства внутрішніх справ України під час проведення огляду місия пожежі, виявлення, припинення, попередження та розслідування кримінальних правопорушень та інших подій, пов'язаних з пожежами» (зареєстрований в Мін’юсті 14.08.2017 за № 998/30866) (Офіційний вісник України, 2017 р., № 72, ст. 2216). 
10. Климась Р.В. Запровадження критеріїв дослідження пожеж дослідно-випробувальними лабораторіями. Запобігання надзвичайним ситуачіям $i$ ̈̈х ліквідація: матеріали науково-практичного семінару. Харків: НУЦЗ України, 2018. С 24-26.

11. Наказ Мін’юсту від 08 жовтня 1998 р. № 53/5 «Про затвердження Інструкиії про призначення та проведення судових експертиз та експертних досліджень та Науково-методичних рекомендацій з питань підготовки та призначення судових експертиз та експертних досліджень» (зареєстрований в Мін’юсті 03.11.1998 за № 705/3145) (Офіційний вісник України, 1998 р., № 46, ст. 1715).

DOI https://doi.org/10.30525/978-9934-26-074-2-63

\title{
СЛІДЧИЙ ЕКСПЕРИМЕНТ: ПОНЯТТЯ, МЕТА І ЗАВДАННЯ
}

\author{
Курнасва К. Г. \\ ад 'юнкт аспірантури кафедри кримінального прочесу \\ та криміналістики \\ Донецького юридичного інституту \\ Міністерства внутрішніх справ Украӥни \\ м. Маріуполь, Донещька область, Украӥна
}

Під час проведення досудового розслідування незалежно від ступеня тяжкості розслідуваного кримінального правопорушення нерідко виникає реальна необхідність у перевірці слідчих версій, усуненні суперечностей в матеріалах кримінального провадження, визначенні ступеню поінформованості злочинців про вчинену подію злочину тощо. У зазначених випадках головним засобом рішення даних проблем $\epsilon$ проведення такої слідчої (розшукової) дії як «слідчий експеримент».

До недавнього часу слідчий експеримент разом із перевіркою показань на місці скоєння злочину були частиною слідчої (розшукової) дії, яка за Кримінальним процесуальним кодексом (КПК) України 1960 р. називалася «відтворення обстановки та обставин події». Таким чином законодавець України у КПК 2012 р. застосував найменування «слідчий експеримент», традиційно використовуване в країнах пострадянського простору.

Провівши ретельний аналіз вироків за результатами розгляду кримінальних проваджень усіх типів злочинів, розміщених на сайті Єдиного реєстру судових рішень, було встановлено, що за 2020 р. та три місяці 2021 р. суди України ухвалили 87610 даних вироків, 3 них 20646 по особливо тяжким злочинам, що складає 23,57 \% від 